\title{
EFFECT OF AGRICULTURAL RESIDUE FIBERS ON NEWSPRINT STRENGTH PROPERTIES
}

\author{
Ivana Plazonić, Željka Barbarić-Mikočević, Nikola Španić \\ UNIVERSITY OF ZAGREB \\ Croatia \\ (Received November 20I9)
}

\begin{abstract}
As newsprints, mostly made from recycled wood pulp, are not high quality papers according to its optical, mechanical and chemical characteristics, in this research the usage of straw pulp as an alternative raw material was analyzed. For that purpose, straw pulp was mixed with recycled wood pulp and strength properties of laboratory made papers were determined according to TAPPI standards. Selection of agricultural waste for preparing straw pulp was based on annual yield of crop species (Triticum spp., Hordeum vulgare L. and Triticale sp.). Results indicated that straw pulp can be efficiently used in portions up to $20 \%$ as a substitute for wood fibers or as an additive in order to obtain particular newsprint properties.
\end{abstract}

KEYWORDS: Straw, pulp, newsprint, fibers length, strength properties.

\section{INTRODUCTION}

In the context of challenging environmental issues, such as reducing deforestation and natural disasters availability of virgin cellulose fibers from wood raw materials is significantly decreased. The global deforestation rate is still high (Indarto and Mutaqin 2016), so there is a potential shortage of conventional wood raw material for the pulp industry. On the other hand, the demand for pulp and paper fiber resources has increased significantly due to increased consumption of various types of paper products and the fast population growth rate (Azeez 2018). In developed countries the rate of paper recycling is growing continuously and many of the mills worldwide use as much as $100 \%$ waste paper as raw material base (Rhyner et al. 1995). However, the lack of such raw material is a paper as a final product with poorer mechanical properties due to a decrease in the interfiber bonding (Ibrahim 2003, Fišerová et al. 2013). Therefore, during papermaking process from recycled pulp, definite percentage of pulp with virgin wood fibers must be added to provide the desired strength of paper (Minor and Atalla 1992). For reducing hardwood consumption, either as basic raw material or as supplement, paper industry is forced to find alternative sources of fibrous raw material, particularly those based on agricultural 
products (Samariha et al. 2013). Considering that all plants contain cellulose in a greater or lesser percentage, pulp can be produced from any wood or non-wood plant. Although the grain of corps is important agricultural product for many countries all around the world, the residues from the corps are largely wasted. One of the most abundant and renewable lignocelullosic agricultural residues is the straw, which is left in the fields, burned or plugged back into the fields after harvesting (Ren et al. 2019). Converting this lignocellulosic residue to pulp for paper would be an advantageous way to utilize it as the consumption of paper is increasing rapidly in in all developed countries.

A rational waste management in some part of the world is recognized because it hides many candidates for paper feedstock. Researches all over the world are dealing with alternative nonwood raw materials for pulp and paper industry, due its: chemical compositions, appropriate process of fibers isolation which will provide quality pulp, usage for different grades of paper products, possibility to provide adequate, optical, mechanical and reproduction quality and recycling efficiency of such products. Until now, only about $2 \%$ of the raw materials involved in papermaking in USA and Europe are non-wood fibers (Grossmann 2009), where they are used mainly for cardboards and fluting papers (Schall et al. 2009). One of the most investigated agricultural residues for the pulp and paper industry is wheat straw (Potůček and Gurung 2014). This is understandable as wheat is the most widely cultivated crop in the world (Curtis 2016) which consequently generates substantial quantities of residues of about 529 million tons worldwide every day (Govumoni et al. 2013). Utilization of wheat straw for the pulp and paper production has some deficiencies such as low pulp yield and problems with the recovery of spent pulping liquors by soda pulping process (Veisi and Mahdavi 2016). On a global scale so far wheat straw pulp, carried out by soda-anthraquinone process, has proven to be a good substitute for old corrugated cardboard (OCC) pulp for making fluting paper. Namely, blending of wheat straw soda - anthraquinone pulp with OCC pulp in different ratios significantly improved all the paper properties, except tear index, compared to 100\% OCC pulp (Schall et al. 2009).

In previous research (Plazonić et al. 2016) conducted chemical component analysis showed that wheat, barley and triticale straw contain high amounts of cellulose, which was the first step of its valorization as a source of fibers in papermaking industry. In this research, emphasis was placed on the potential value of straw for pulp and papermaking based on strength properties of newsprint produced at laboratory scale. As newsprint represents a lower grade paper, along with accepting four-color printing (CMYK) paper strength properties are important indicators of the quality of newsprint as a printing substrate. For that purpose, the tensile index, tear index and burst index of newsprint, formed from recycled pulp in admixture with a variable content of straw pulp, were determined.

\section{MATERIAL AND METHODS}

\section{Materials (straw - pulp - paper)}

The straw of three most common crop species in Croatia e.g. wheat (Triticum spp.), barley (Hordeum vulgare L.) and triticale (Triticale sp.) was collected after the harvest. Cleaned straw was manually cut using scissors into approximately $3 \mathrm{~cm}$ long pieces and conducted into semichemical pulp according soda pulping method (Plazonic et al. 2016) by degrading the lignin and hemicelluloses into small water-soluble molecules which were washed away from the cellulose fibers. 
After the thermal treatment which was carried out in automatic autoclave (Kambič) under the controlled and defined conditions (Tab. 1), the pulp slurry was removed from black process liquor by decantation. Thereafter, softened pulp was rinsed in two cycles with tap water and had been transferred into Valley beater (Techlab Systems (TLS)) where appropriate amount of tap water was added in order to maintain the pulp suspension at $1.5 \%$ consistency. The fiberization

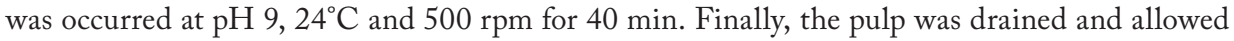
to dry to moisture content of approximately $7 \%$ at the room temperature.

Tab. 1: Soda pulping conditions.

\begin{tabular}{|c|c|}
\hline Straw & Pulping conditions \\
\hline Wheat & \multirow{3}{*}{$\begin{array}{l}\text { Temperature of } 120^{\circ} \mathrm{C} \text {, alkali level of } 16 \% \text { for } \\
60 \text { min and a } 10: 1 \text { liquid-biomass ratio. }\end{array}$} \\
\hline Barley & \\
\hline Triticale & \\
\hline
\end{tabular}

In disintegration stage of paper production process, obtained unbleached straw pulp was added in proportions of $10 \%, 20 \%$ and $30 \%$ to reference pulp. Reference pulp was recycled pulp, used for newsprint in many printing presses for printing newspapers, supplied in the form of dry sheets. In order to estimate the effect of straw fibers on newsprint strength properties, laboratory sheets of approximately $45 \mathrm{~g} \cdot \mathrm{m}^{-2}$ were formed in a Rapid-Köthen sheet former (FRANK-PTI) according to standard EN ISO 5269-2:2001. In total, according to its composition 10 different laboratory made newsprints were formed (Tab. 2).

Tab. 2: Pulp proportions for laboratory made newsprint.

\begin{tabular}{|l|c|}
\hline \multicolumn{1}{|c|}{ Pulp blends } & Proportions \\
\hline recycled wood & 100 \\
\hline recycled wood : wheat & $90: 10 ; 80: 20 ; 70: 30$ \\
\hline recycled wood : barley & $90: 10 ; 80: 20 ; 70: 30$ \\
\hline recycled wood : triticale & $90: 10 ; 80: 20 ; 70: 30$ \\
\hline
\end{tabular}

\section{Methods}

Fiber length determination

According to slightly modified Franklin's method (Chaffey 2002), each specimen intended for fiber length determination was macerated in 1:1 (v/v) mixture of glacial acetic acid and 30\% hydrogen peroxide. Maceration took place in $35 \mathrm{ml}$ scintillation vials that have been heated for $48 \mathrm{~h}$ to $60^{\circ} \mathrm{C}$ using dry block heater (IKA, Dry block heater 1). After the specified time elapsed almost pure white delignified samples were obtained. Macerating solution was then carefully decanted, and the samples were rinsed with distilled water for several times. In order to neutralize the remaining traces of acetic acid small amounts of sodium carbonate were added to half-filled vials containing samples in distilled water. Sodium carbonate was added in small amounts at the time ensuring that effervescence is not so vigorous that it breaks up the delignified straw samples. When the effervescence has stopped the liquid from the vials was decanted and samples were rinsed several times with distilled water in order to remove the traces of sodium carbonate. Finally, individual fibers were produced by vigorously shaking the delignified straw samples in vials half-filled with distilled water. Such fibers were then dyed using Toluidine Blue O dye and observed using Zeiss AXIO Zoom V16 microscope. For each specimen type, the lengths of 50 randomly selected fibers were measured using AxioVision SE64 (Rel. 4.9.1) software. All the 
chemicals used in the pulp preparation were purchased from Kemika Ltd., Croatia. Toluidine Blue $\mathrm{O}$ dye was purchased from Sigma-Aldrich, Germany.

\section{Strength properties of laboratory made newsprint}

All strength properties of laboratory prepared newsprints were tested in accordance with appropriate TAPPI standards (Tab. 3). Each test was repeated ten times and the average of these tests was used to determine the effect of addition of fibers from each straw pulp on newsprint strength properties prepared from recycled wood pulp at laboratory scale. Standard deviation (SD) for each measured and calculated strength property was also noted.

Tab. 3: Analysis of strength properties.

\begin{tabular}{|l|c|}
\hline \multicolumn{1}{|c|}{ Strength property } & TAPPI standard method of analysis \\
\hline Tensile breaking properties & T494 om-01 \\
\hline Tearing resistance & T414 om-12 \\
\hline Bursting strength & T403 om-97 (Mullen tester) \\
\hline Surface strength (wax picking test) & T459 om-93 \\
\hline
\end{tabular}

\section{RESULTS AND DISCUSSION}

The strength properties of paper samples are substantially influenced by individual characteristics of cellulose fibers as well as by the paper network structure. It is important to say how this research was studied at laboratory scale. Namely, in laboratory made newspapers fibers are not properly oriented as in commercial papers, due to the way of functioning semiautomatic Rapid-Kothen sheet former used for making laboratory sheets. However, lengths of those individual fibers surely define structure of laboratory papers and thus its strength properties (Plazonić et al. 2016). Microscopic images of fibers from each cereal straw captured during fiber length determination are presented at Fig. 1.
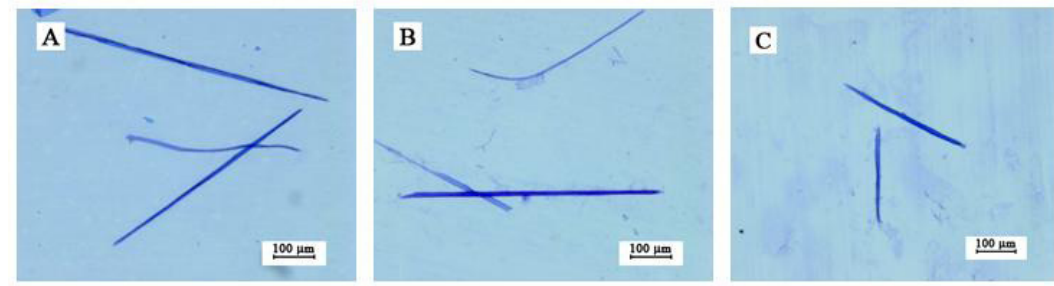

Fig. 1: Micro images of fibres (168x magnification): wheat (A), barley (B) and triticale (C).

Newsprint is predominantly recycled fiber based paper where it is important to emphasize how by each recycling process fibers become shorter. So, blending with longer fibers is extremely important during newsprint production because length is one of the most important fiber properties which effects on the strength properties of the pulp and the paper made of it. A long fiber pulp is good to blend with short fiber pulp to optimize on fiber cost, strength and formation 
of paper. In general, usage of longer fibers will increase the number of bonds per fiber, which will lead to more strongly bound of fibers into the network, thereby increasing the strength of fiber network in paper (Keränen and Retulainen 2016). As virgin straw fibers should be used as enrichment for recycled fibers instead wood fibers, fibers length determine for each analyzed straw is listed in Tab. 4. The differences among straw of crop species in fiber length are visible.

Tab. 4: Fibers length of straw conducted to pulp for newsprint production.

\begin{tabular}{|c|c|c|c|c|c|}
\hline \multirow{2}{*}{ Raw material } & \multirow{2}{*}{ Species } & \multicolumn{4}{|c|}{ Fibers length (mm)* } \\
\hline & & Mean & SD & Min & Max \\
\hline \multirow{3}{*}{ Straw } & Wheat (Triticum spp.) & 0.83 & 0.26 & 0.45 & 1.62 \\
\hline & Barley (Hordeum vulgare L.) & 0.91 & 0.29 & 0.40 & 1.62 \\
\hline & Triticale (Triticale sp.) & 0.93 & 0.61 & 0.27 & 2.63 \\
\hline
\end{tabular}

*Values based on lengths of 50 fibers measured for each examined species.

If mean values in Tab. 4 are observed it can be concluded that all corps straw contained short fibers with a mean length of $0.83 \mathrm{~mm}$ for wheat, $0.91 \mathrm{~mm}$ for barley and $0.93 \mathrm{~mm}$ for triticale one. It was noted that straw fibers are heterogeneous in a character, with a considerably large range in fiber length. Namely, wheat and barley straw consist of fibers whose length ranges from 0.45 to $1.62 \mathrm{~mm}$, while the range for triticale fibers is much wider $(0.27-2.63 \mathrm{~mm})$. However, for all analyzed straws most fibers are in the range from 0.5 to $0.9 \mathrm{~mm}$, approximately $76 \%$ of the wheat, $68 \%$ of barley and only $36 \%$ of the triticale fibers (Španić et al. 2018). Generally, gained results for fiber length are in correlation with other researches reports. The most studied straw is wheat straw and consequently the most information about fiber length is available for this type of straw. Mean fiber length of wheat straw publish by Deniz is $0.738 \mathrm{~mm}$ by Deniz et al. (2004), by Guo is $0.68 \mathrm{~mm}$ by Guo et al. (2009) while by Favadi and by Singh is $1.18 \mathrm{~mm}$ (Fadavi et al. 2012, Singh et al. 2011). El Mansouri has published that average length of triticale fibers is 0.926 mm (E1 Mansouri et al. 2012).

After the experiment data processing, the effects of varies blending levels of two pulp types (straw pulp and recycled pulp) on the strength properties (tensile index, tear index, burst index and critical wax strength number (CWSN) of the laboratory made newsprint sheets was established. All gained strength properties results are summarized in Tab. 5. The effect of each straw pulp on strength properties of laboratory newsprint sample were shown by comparison with reference sample ( $0 \%$ of straw pulp). It is observed that inhomogeneity of all laboratory made newsprint samples affects the results of the mechanical properties measurements and shows results, which have a high standard deviation. 


\section{WOOD RESEARCH}

Tab. 5: Strength properties of the laboratory made pulp sheets: a) wheat, b) barley, c) triticale.

\begin{tabular}{|c|c|c|c|c|c|c|c|c|c|}
\hline \multirow{3}{*}{\multicolumn{2}{|c|}{ a) Wheat }} & \multicolumn{8}{|c|}{ Pulp (\%) } \\
\hline & & Straw & Recycled & Straw & Recycled & Straw & Recycled & Straw & Recycled \\
\hline & & \multirow{2}{*}{\multicolumn{2}{|c|}{43.61}} & \multirow{2}{*}{\multicolumn{2}{|c|}{41.80}} & \multirow{2}{*}{\multicolumn{2}{|c|}{41.02}} & \multirow{2}{*}{\multicolumn{2}{|c|}{41.02}} \\
\hline \multirow{3}{*}{$\begin{array}{l}\text { Tensile index } \\
\left(\mathbf{N m} \cdot \mathrm{g}^{-1}\right)\end{array}$} & Mean & & & & & & & & \\
\hline & SD & \multicolumn{2}{|c|}{3.45} & \multicolumn{2}{|c|}{2.01} & \multicolumn{2}{|c|}{2.40} & \multicolumn{2}{|c|}{1.61} \\
\hline & Range & \multicolumn{2}{|c|}{$36.62-46.23$} & \multicolumn{2}{|c|}{$40.36-47.60$} & \multicolumn{2}{|c|}{$39.07-47.08$} & \multicolumn{2}{|c|}{$38.26-43.35$} \\
\hline \multirow{3}{*}{ Elongation (\%) } & Mean & \multicolumn{2}{|c|}{1.23} & \multicolumn{2}{|c|}{1.35} & \multicolumn{2}{|c|}{1.4} & \multicolumn{2}{|c|}{1.4} \\
\hline & SD & \multicolumn{2}{|c|}{0.25} & \multicolumn{2}{|c|}{0.18} & \multicolumn{2}{|c|}{0.09} & \multicolumn{2}{|c|}{0.12} \\
\hline & Range & \multicolumn{2}{|c|}{$0.7-1.5$} & \multicolumn{2}{|c|}{$1.1-1.6$} & \multicolumn{2}{|c|}{$1.3-1.5$} & \multicolumn{2}{|c|}{$1.2-1.6$} \\
\hline \multirow{3}{*}{$\begin{array}{c}\text { Tear index } \\
\left(\mathrm{mN} \cdot \mathrm{m}^{2} \cdot \mathrm{g}^{-1}\right)\end{array}$} & Mean & \multicolumn{2}{|c|}{9.20} & \multicolumn{2}{|c|}{10.18} & \multicolumn{2}{|c|}{9.12} & \multicolumn{2}{|c|}{9.57} \\
\hline & SD & \multicolumn{2}{|c|}{1.05} & \multicolumn{2}{|c|}{0.83} & \multicolumn{2}{|c|}{1.01} & \multicolumn{2}{|c|}{0.50} \\
\hline & \begin{tabular}{|l|} 
Range \\
\end{tabular} & 7.95 & -11.00 & 9.05 & -11.13 & 7.97 & -10.50 & 9.11 & 10.21 \\
\hline & Mean & & 3.54 & & .69 & & .07 & & .41 \\
\hline Burst index & SD & & .27 & & 25 & & 32 & & 85 \\
\hline$\left(\mathrm{kPa} \cdot \mathrm{m}^{2} \cdot \mathrm{g}^{-1}\right)$ & Range & 13.19 & -13.97 & 13.26 & -14.23 & 12.44 & -13.70 & 12.69 & -15.60 \\
\hline CWSN & & & $7 \mathrm{~A}$ & & $7 \mathrm{~A}$ & & A & & A \\
\hline
\end{tabular}

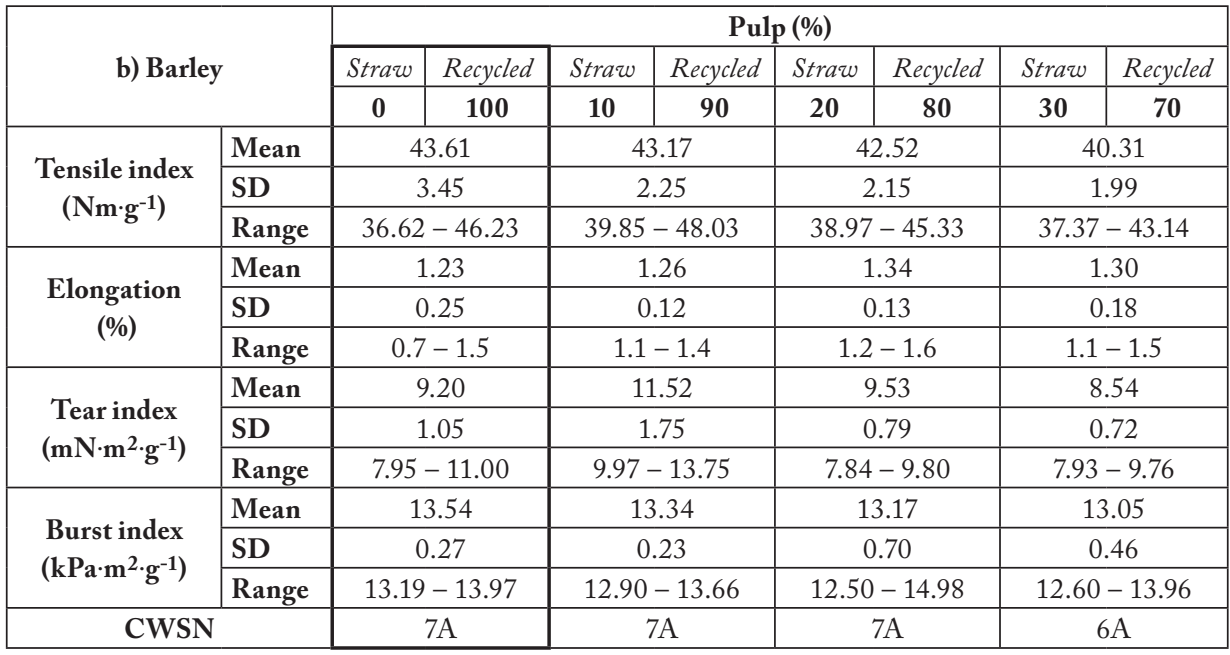

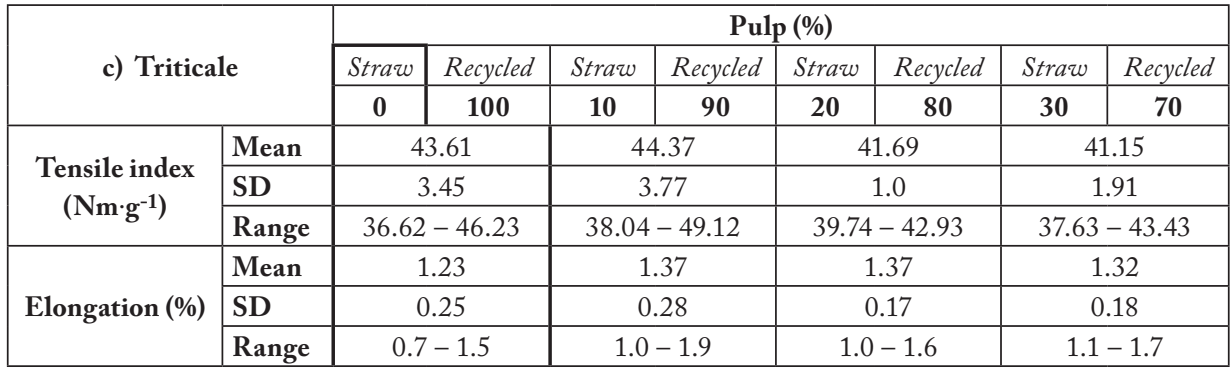


Vol. 65 (3): 2020

\begin{tabular}{|c|l|c|c|c|c|}
\hline \multirow{2}{*}{$\begin{array}{c}\text { Tear index } \\
\left(\mathbf{m N} \cdot \mathbf{m}^{\mathbf{2}} \cdot \mathbf{g}^{-\mathbf{1}}\right)\end{array}$} & Mean & 9.20 & 9.95 & 9.10 & 10.03 \\
\cline { 2 - 6 } & SD & 1.05 & 1.80 & 0.32 & 0.82 \\
\cline { 2 - 6 } & Range & $7.95-11.00$ & $8.28-12.55$ & $8.78-9.55$ & $9.50-11.40$ \\
\hline \multirow{2}{*}{$\begin{array}{c}\text { Burst index } \\
\left(\mathbf{k P a} \cdot \mathbf{m}^{2} \cdot \mathbf{g}^{-1}\right)\end{array}$} & Mean & 13.54 & 13.61 & 12.88 & 13.03 \\
\cline { 2 - 6 } & SD & 0.27 & 0.25 & 1.42 & 0.64 \\
\cline { 2 - 6 } & Range & $13.19-13.97$ & $13.24-14.09$ & $10.00-15.43$ & $12.31-14.56$ \\
\hline \multicolumn{2}{|c|}{ CWSN } & $7 \mathrm{~A}$ & $7 \mathrm{~A}$ & $6 \mathrm{~A}$ & $6 \mathrm{~A}$ \\
\hline
\end{tabular}

In general, addition of straw pulp, regardless to the crop type, has not shown any significant negative influence on strength properties of paper. Furthermore, reference sample with $0 \%$ of straw pulp has the minimum measured tensile index $36.62 \mathrm{Nm} \cdot \mathrm{g}^{-1}$, while all samples with straw pulp have the higher value of minimum measured tensile index (in range $37.37-40.36 \mathrm{Nm} \cdot \mathrm{g}^{-1}$ ). The maximum measured tensile index of reference sample was $46.23 \mathrm{Nm} \cdot \mathrm{g}^{-1}$; while for samples with straw pulp this parameter was in range $43.14-48.03 \mathrm{Nm} \cdot \mathrm{g}^{-1}$. There were no significant differences between tensile index of sheets made of pure recycled pulp and those with 10\%-30\% straw pulp/90\% $-70 \%$ recycled pulp blended. From tensile index results, it could be expected that commercial papers with addition of straw pulp (wheat, barley or triticale) would have similar or even better tensile index as papers made only from recycled wood pulp. During tensile breaking properties determination, elongation of the strip of each laboratory newsprint sample is recorded as well as an insight into the percentage increase in length of the test strip when fracture occurs divided by the original length of the test strip. From gained results, it is evident that addition of all straw pulp types in all observed shares increases the relative elongation of laboratory newsprint samples. The recorded relative elongation average value of reference sample was $1.21 \%$, while for papers with $10 \%-30 \%$ wheat pulp was $1.35 \%-1.40 \%$; barley pulp was $1.26 \%-1.34 \%$ and triticale pulp was $1.37 \%-1.32 \%$. Again, the minimum measured relative elongation $0.7 \%$ was for reference sample, while all samples with straw pulp have the higher value of minimum measured relative elongation (in range $1.0 \%-1.3 \%$ ).

It was noted that the minimum tear index value of all sheets produced with addition of straw pulp was higher comparable with value obtained for reference sample $\left(7.95 \mathrm{mN} \cdot \mathrm{m}^{2} \cdot \mathrm{g}^{-1}\right)$. Results displayed on Tab. 5 showed that the addition of straw pulp produce laboratory newsprint with similar or slightly lower average burst index value compare to recycled pulp in reference sample. In general, from all analyzed straw pulp, wheat pulp has shown the most positive influence on burst index of laboratory newsprint sheets. This result could be connected with fiber length results as the longer and stronger fibers provide higher strength properties. Namely, the smallest measured fiber in macerated wheat straw was $0.45 \mathrm{~mm}$; while in barley and especially in triticale straw the smallest fiber was significantly shorter (min length of barley fiber was $0.40 \mathrm{~mm}$ and triticale fiber $0.27 \mathrm{~mm})$.

Since wax sticks are used as analogues for hot melt adhesives, measurements were made of their tensile strength using the pull-off test to determine how well they replicate the properties of the adhesives. The tensile strength of the wax appears to increase with wax number, which means that the higher the CWSN indicate the stronger paper surface strength or its resistance to picking. As newsprint is grade of paper, which is intended entirely for printing, surface strength is an important parameter as it relates to the forces created during printing. Picking denotes damaging the paper surface during printing operation due to forces imposed by lifting-off the printing equipment from the paper surface. These forces depend on ink viscosity and printing speed. If they exceed the surface strength of paper, picking begins. In other words, a low surface strength of paper may create picking problems (Drobchenko 2004). The CWSN results indicate 
that addition of straw pulp into recycled pulp does not significantly change surface strength of laboratory made newsprint. In comparison with reference sample, where determinate CWSN was $7 \mathrm{~A}$, only papers with triticale pulp have shown some lower surface strength $(\mathrm{CWSN}=6 \mathrm{~A})$ when the share of straw pulp was higher than $10 \%$. Surface strength is the ability of paper to resist a force pulling fibers or fiber bundles from its surface and is strongly influenced by the type of fibers used in papermaking process. As long fibers are improving the surface strength properties of the paper, it is evident why papers with triticale pulp have shown the lower surface strength. Namely, in macerated triticale straw the shortest fibers were detected (fibers with length of 0.27 $\mathrm{mm}$ ). However, acceptable pick level for commercial uncoated papers is at least 7A (Board 2003) and all laboratory newsprint papers without any surface treatment have sufficient surface strength for printing process.

\section{CONCLUSIONS}

The straw as agricultural residues, in general, and wheat straw, in particular, can be successfully considered as an alternative, replacing the pulp produced from recovered paper. It has been noticed from this study that straw pulp gained from wheat, barley and triticale agricultural species can act as a good strength fiber enrichment of paper sheets made from repulped recycled newsprint when added in portions up to $20 \%$, while in range from $20 \%$ to $30 \%$ strength properties vary depending on straw source. Overall, fiber length of all analyzed straw fibers is satisfactory for papermaking, although, they would be classified as short fibers. Based on gained results it could be concluded that straw fibers can be efficiently used in small portions as a substitute for more expensive wood fibers or as an additive in order to obtain particular paper properties.

\section{ACKNOWLEDGMENTS}

The authors are grateful for the funding provided by the University of Zagreb.

\section{REFERENCES}

1. Azeez, M.A., 2018: Pulping of non-woody biomass. Chapter 3. In: Pulp and Paper Processing (ed. Kazi, S.N). IntechOpen, London, Pp 55-86.

2. Board, N., 2003: The complete book on printing technology. Asia Pacific Business Press Inc. India, $742 \mathrm{pp}$.

3. Chaffey, N., 2002: Wood microscopical techniques. In: Wood formation in trees: cell and molecular biology techniques (ed. Chaffey, N.). CRC Press, Boca Raton, Pp 23-24.

4. Deniz, I., Kirc1, H., Ates, S., 2004: Optimization of wheat straw triticum drum kraft pulping. Industrial Crops and Products 19(3): 237-243.

5. Drobchenko, A., 2004: Automated picking assessment using machine vision. MSc (Diploma) thesis, Lappeenranta University of Technology, $71 \mathrm{pp}$.

6. E1 Mansouri, N.E., Espinach, F.X., Julian, F., Verdaguer, N., Torres, L., Llop, M. F., Mutje, P., 2012: Research on the suitability of organosolv semi-chemical triticale fibers as reinforcement for recycled HDPE composites. BioResources 7(4): 5032-5047.

7. Fadavi, F., Kermanian, H., Resalat, H., 2012: Effect of fiber fractionation on refinability and strength properties of wheat straw soda-aq pulp. Lignocellulose 1(2): 153-163. 
8. Fišerová, M., Illa, A., Boháček, Š., Kasajová, M., 2013: Handsheet properties of recovered and virgin fibre blends. Wood Research 58(1): 57- 66.

9. Govumoni, S.P., Koti, S., Kothagouni, S.Y., Venkateshwar, S., Linga, V.R., 2013: Evaluation of pretreatment methods for enzymatic saccharification of wheat straw for bioethanol production. Carbohydrate Polymers 91(2): 646-650.

10. Grossmann, H., 2009: The limits of paper recycling - an European approach to identify and extend the limits of paper recycling. In: 2007 TAPPI $8^{\text {th }}$ Research Forum on Recycling. Pp 1-8.

11. Guo, S., Zhan, H., Zhang, C., Fu, S., Heijnesson-Hultén, A., Basta, J., Greschik, T., 2009: Pulp and fiber characterization of wheat straw and eucaluptus pulps - a comparison. BioResources 4(3): 1006-1016.

12. Ibrahim, R., 2003: Structural, mechanical and optical properties of recycled paper blended with oil palm empty fruit bunch pulp. Journal of Oil Palm Research 15(2): 28-34.

13. Indarto, J., Mutaqin, D.J., 2016: An overview of theoretical and empirical studies on deforestation. Journal of International Development and Cooperation 22(1-2): 107-120.

14. Keränen, J.T., Retulainen, E., 2016: Changing quality of recycled fiber material. Part 1. Factors affecting the quality and an approach for characterisation of the strength potential. BioResources 11(4): 10404-10418.

15. Minor, J.L., Atalla, R.H., 1992: Strength loss in recycled fibers and methods of restoration. In: Proceedings of Materials Research Society symposium. San Francico, CA. Pittsburg, PA: Materials Research Society, vol. 266: Pp 215-228.

16. Plazonić, I., Barbarić-Mikočević, Ž., Antonović, A., 2016: Chemical composition of straw as an alternative material to wood raw material in fibre isolation. Drvna industrija 67(2): 119-125.

17. Plazonić, I., Barbarić-Mikočević, Ž., Bates, I., 2016: Strength properties of newsprint from recovered paper in admixture with wheat pulp. Proceedings of $8^{\text {th }}$ international symposium on graphic engineering and design (ed. Pavlović, Ž.). Novi Sad: Grafički centar GRID, Serbia, Pp 201-206.

18. Plazonic, I., Bates, I., Barbaric-Mikocevic, Z., 2016: The effect of straw fibers in printing papers on dot reproduction attributes, as realized by UV inkjet technology. BioResources 11(2): 5033-5049.

19. Potůček, F., Gurung, B., 2014: Strength characteristics of chemi-mechanical pulp from rapeseed straw. Acta Facultatis Xylologiae Zvolen 56(1): 51-57.

20. Ren, J., Yu, P., Xu, X., 2019: Straw utilization in China - status and recommendations. Sustainability 11(6): 1762.

21. Rhyner, C.R., Schwartz, L.J., Wenger, R.B., Kohrell, M.G., 1995: Waste Management and Resource Recovery. CRC Press. Boca Raton, 544 pp.

22. Samariha, A., Khakifirooz, A., Nemati, M., Ravanbakhsh, F., Kiaei, M., Saghafie, A., 2013: Newsprint from NSSC bagasse pulp mixed with hardwood CMP pulp and bleached softwood kraft pulp. BioResources 8(4): 5561-5569.

23. Schall, N., Kruger, E., Blum, R., Rubenacker, M., 2009: Soda-AQ pulping of wheat straw and its blending effect on old corrugate cardboard (OCC) pulp properties. Tappsa Journal: 35-39.

24. Singh, S., Dutt, D., Tyagi, C. H., 2011: Complete characterization of wheat straw (Triticum aestivum PBW-343 1. EMEND. FIORI \& PAOL.). A renewable source of fibres for pulp and papermaking. BioResources 6(1): 154-177. 
25. Španić, N., Plazonić, I., Jambreković, V., Barbarić-Mikočević, Ž., 2018: Wood and nonwood fibres length as main factor affecting their suitability as raw materials for papermaking industry. In: Proceedings of Natural resources, green technology and sustainable development/3. University of Zagreb, Croatia, Pp 121-125.

26. Veisi, A., Mahdavi, S., 2016: Mixing bleached white poplar and wheat straw chemimechanical pulps to improve the mechanical and optical characteristics. BioResources 11(2): 2987-2997.

Ivana Plazonić*, ŽElejka Barbarić-Mikočević

University of Zagreb

Faculty of Graphic Arts

Department of Fundamental and General Knowledge

Chair of Applied Chemistry

IO OOO ZAGREB

Croatia

*Corresponding author: ivana.plazonic@grf.hr

\author{
Nikola Španić \\ University OF ZAGReb \\ FACULTY OF ForESTRY \\ Department of Wood Technology \\ IO OOO ZAgreb \\ Croatia
}

